\title{
Lower limb muscle strength and serotonin receptor gene polymorphism as factors associated in women with fibromyalgia
}

Luana Oliveira de Lima ${ }^{1,2,3}$, Carlos Alexandre Martins Zicarelli, ${ }^{1,2,3}$, Andressa Saori Matsumura ${ }^{3}$, Layse Rafaela Moroti-Perugini, ${ }^{1,2,3}$, Denilson de Castro Teixeira ${ }^{2}$, Karen Barros Parron Fernandes ${ }^{1,2}$, Priscila Daniele de Oliveira Perrucini ${ }^{2,3,4}$ and Regina Célia Poli-Frederico ${ }^{1,2,3^{*}}$

\begin{abstract}
Background: Fibromyalgia (FM) is a chronic pain syndrome characterized by generalized skeletal muscle chronic pain. Its etiology is not well defined, because there are several factors that may trigger it such as physical and/or emotional stresses, or a genetic susceptibility, involving serotonergic, dopaminergic and catecholaminergic paths. The objective of this study was to investigate the association between the strength of the lower limb, genetic polymorphism of the serotonin receptor gene $\mathrm{HTR}_{2 \mathrm{~A}}$ in women with fibromyalgia.
\end{abstract}

Methods: In this observational study of case-control type 48 women were evaluated who belonged to the group with FM (52 \pm 12 years) and 100 women in the control group (58 \pm 11 years). Socio demographic and anthropometric data were collected and peripheral blood samples for DNA extraction; genotypic analyzes were performed by means of PCR in real time by TaqMan ${ }^{\circledR}$ system. The lower limb muscle strength was assessed through the test of sitting down and standing up for $30 \mathrm{~s}$. The chi-square test or Fischer Exact was used for possible associations among the variables; the t-test for independent samples was used to compare the averages among the groups; the value of significance adopted was $5 \%$.

Results: There was an association between the polymorphism of the HTR2A gene with FM, demonstrating that carriers of the genotype GG have 24.39 times more likely to develop the syndrome (IC95\% 5.15-115.47; $p=0.01$ ). It was observed an association between FM and the test to sit and stand up demonstrating that women with fibromyalgia have lower limb muscle strength $(p=0.01)$. The study showed that the white race has 3.84 times more likely to develop FM $(p=0.01)$.

Conclusion: The results of this study suggest that women of Caucasian ethnicity with GG genotype or G allele presented greater risk of developing fibromyalgia and that these patients have lower limb muscle strength compared to the control group.

Keywords: Fibromyalgia, Genetic polymorphism, Muscle strength, Serotonin receptor HTR2A, Women

\footnotetext{
* Correspondence: reginafrederico@yahoo.com.br

${ }^{1}$ Rehabilitation Sciences State University of Londrina and University Pitágoras

Unopar (UEL/UNOPAR), Londrina, PR, Brazil

${ }^{2}$ Departament of Physical Education and Sport, Londrina State University

(UEL), Londrina, Paraná, Brazil

Full list of author information is available at the end of the article
}

(c) The Author(s). 2019 Open Access This article is distributed under the terms of the Creative Commons Attribution 4.0 International License (http://creativecommons.org/licenses/by/4.0/), which permits unrestricted use, distribution, and reproduction in any medium, provided you give appropriate credit to the original author(s) and the source, provide a link to the Creative Commons license, and indicate if changes were made. The Creative Commons Public Domain Dedication waiver (http://creativecommons.org/publicdomain/zero/1.0/) applies to the data made available in this article, unless otherwise stated. 


\section{Introduction}

Fibromyalgia (FM) is a chronic pain syndrome characterized by generalized skeletal muscle chronic pain, usually accompanied by symptoms of fatigue, sleep and mood disorders, cognitive changes, digestive problems, among others $[1,2]$. These symptoms lead these patients to suffer from functional and cognitive disabilities, leading to a decrease in the daily activities, work and leisure, generating signs of anxiety and depression, significantly affecting the quality of life of these people [3]. Studies have shown that the functionality of fibromyalgia sufferers is reduced, and they also have a decrease in muscle strength, stamina and balance, and these factors increase the fragility of these individuals [4-6]. It affects 3 to $6 \%$ of the world population, and in Brazil reaches $2.5 \%$ of the Brazilian population, being the second most frequent rheumatological disorder, affecting mainly women [7-9].

Its etiology is not well defined, because there are several factors that can trigger the symptoms, such as physical, emotional or environmental stress. Additionally, it may be associated with changes in the central mechanism of pain control, presenting dysfunction in neurotransmitters, which may lead to a deficiency of inhibitory neurotransmitters, and to a hyperactivity of excitatory neurotransmitters $[10,11]$. This mechanism may be related to a genetic susceptibility, involving serotonergic, dopaminergic and catecholaminergic paths [12]. Studies emphasize that genetic factors may account for up to $50 \%$ susceptibility to the syndrome, considering gene-environment interaction as a triggering factor [13].

Serotonin $(5-\mathrm{HT})$ is an important neurotransmitter that performs several functions in the central nervous system, such as regulation of sleep, body temperature, appetite, humor, motor activity and perception of pain, among others [14-16]. Low serotonin concentrations have been associated with fibromyalgia patients [17]. Studies demonstrate that the serotonin receptor gene HTR2A located on the long arm of chromosome 13 (13q14-q21), presents certain genetic polymorphisms. One of them, located in the promoter region - 1438(A > G) RS6311, has been associated with some diseases such as rheumatoid arthritis and fibromyalgia [18-21]. It should be emphasized that this polymorphism is a TagSNP and is in a perfect linkage disequilibrium with other SNPs, namely, $102 \mathrm{~T} / \mathrm{C}$ (rs6313), $-1420 \mathrm{C} / \mathrm{T}$ (rs6306) and -783A/G (rs6312) [22]. Studies show that patients with chronic pain that showed polymorphisms in SNPs $102 \mathrm{~T} / \mathrm{C}$ and -1438A/G of 5-HTR2A may influence the individual differences of sensitivity to pain, this being an important factor that generates functional disability and decreased muscle strength [23-25].

There is need for further investigations to a better understanding of the role of polymorphism in the serotonin receptor gene HTR2A in origin and/or severity of fibromyalgia. Lee et al. [20] and Mergener et al. [21] found an association between fibromyalgia and the polymorphism of the gene $102 \mathrm{~T} / \mathrm{C}$, demonstrating that the carriers of the $\mathrm{C}$ allele present higher risk for the development of the syndrome. However, studies like those of Tander et al. [26] and Matsuda et al. [27] found no statistically significant relationship among the polymorphisms $102 \mathrm{~T} / \mathrm{C}$ and $-1438 \mathrm{~A} / \mathrm{G}$ and fibromyalgia.

Thus, the objective of this study was to the association between the strength of the lower limb, genetic polymorphism of the serotonin receptor gene HTR2A in women with fibromyalgia.

\section{Materials and methods}

The research was approved by the Ethics in Research Committee of the University XXXX under $n^{\circ}$. XXX and all participants signed an Informed Consent Form, which showed their agreement to participate in the study.

\section{Research design and participants}

This study was an observational case-control type, with a quantitative approach. A convenience sample was composed of women from the city of XXX, with an average age of $52.05 \pm 12.19$ years and diagnosed clinically with fibromyalgia by a specialist doctor in neurosurgery and pain treatment $(\mathrm{XXX})$. Power calculation was performed between groups 1 (48) and 2 (100) from the parameters odds ratio $(24,39)$, proportions p2 $(0,5)$ and error $(0,05)$, obtaining the result of $99 \%$. The inclusion criteria were: female patients, older than 18 years with medical clinical diagnosis of fibromyalgia, in accordance with the guidelines of the Amerrican College of Rheumatology (ACR) of 2011 [28]. The control group was composed of women with a mean age of $58 \pm 11$ years without fibromyalgia, without any sign of chronic and diffuse muscle pain and seeking to maximize the equivalation of age and BMI with the participants of the study group.

It was considered an exclusion criterion for both groups: presence of any kind of joint inflammatory disease or degenerative joint disease.

\section{Instruments}

A structured questionnaire was used and standardized, composed by socio-demographic data (gender and age), medications in use and the perception of health in general, as the presence of comorbidities.

For the assessment of muscular strength of lower limbs, sitting down and standing up test was performed. This test consists of sitting down and standing up from a chair with backrest and an approximate height of 43 $\mathrm{cm}$, with their arms crossed over the chest for $30 \mathrm{~s}$. A familiarization was performed, and the number of repetitions was recorded. The classification was performed by means of the calculation of $90 \%$ percentile where they 
were divided in $<9$ as low performance, 10-12 normal performance and $>13$ as high performance [25].

\section{Genetic analysis}

The DNA was obtained from peripheral blood leukocytes by venous puncture in tubes containing EDTA $(0.6 \%)$ using QIAamp kit for extraction of DNA Blood Mini Kit (Qiagen, Germany), following precisely the guidelines provided by the manufacturer. The extracted DNAs were stored in a freezer at $-80^{\circ} \mathrm{C}$ until the analyzes of polymorphism were conducted.

The quality and quantity of DNA was measured through the analysis of the absorbance in a spectrophotometer (Thermo Scientific NanoDrop 2000) to $260 \mathrm{~nm}$ and 280 $\mathrm{nm}$. Then, the DNA dilution was performed in ultra-pure water to obtain a final concentration of $30 \mathrm{ng} / \mathrm{uL}$.

\section{Polymerase chain reaction in real time ( $q P C R$ ) and analysis of the polymorphism of the serotonin receptor gene HTR2A}

With the objective of analyzing the single nucleotide polymorphism (SNP) serotonin receptor HTR2A -1438A/G (rs6311) the technique of amplification of fragments of DNA by polymerase chain reaction was used in real time using the TaqMan ${ }^{\circ}$ system (Applied Biosystems, Foster City, USA). The reaction consisted of a final volume of $10 \mu \mathrm{L}$ being: $5.25 \mu \mathrm{l}$ of Taqman ${ }^{\circ}$ Genotyping Master Mix (1x), 0,5 $\mu \mathrm{L}$ of probe (1x) (Applied Biosystems, Foster City, USA), 3,25 $\mu \mathrm{L}$ of ultrapure water Milli- $\mathrm{Q}^{\circ}$ and $1 \mu \mathrm{L}$ of DNA (30 ng/uL).

Real-time thermal cycler Rotor-Gene $\mathrm{Q}^{\circ}$ (Qiagen, Germany) was used with the cycling of $60^{\circ} \mathrm{C}$ for $30 \mathrm{~s}$ (initial denaturation), $95^{\circ} \mathrm{C}$ for $10 \mathrm{~min}$ for initial denaturation, 50 cycles of $95^{\circ} \mathrm{C}$ for $15 \mathrm{~s}$ (denaturation) and $60{ }^{\circ} \mathrm{C}$ for $1 \mathrm{~min}$ and $30 \mathrm{~s}$ (pairing of initiators and extension) and a final cycle of extension of $30 \mathrm{~s}$ at $60^{\circ} \mathrm{C}$.

For the SNP allele discrimination, the Software Gene Rotor Q - Pure Detection version 2.0.3 (Qiagen, Germany) was used.

\section{Statistical analysis}

It was used the package Statistical Package for Social Science - SPSS (v.2.1, SPSS Inc., Chicago) for the analysis of the data obtained. It was verified the normality of the data by the Shapiro-Wilk test. The absolute and relative frequencies for each variable were calculated. The t-test for independent samples was used for the pairing among the groups. The Chi-square test was used $\left(?^{2}\right)$ for the analysis of association among the variable fibromyalgia and the variables of race, allelic and genotypic frequencies, and the association between fibromyalgia and comorbidities (diabetes, hypertension and heart disease) we used the Fisher Exact test or the Fisher Freeman Halton test for lower limb muscle strength (sit and stand up). For all the analyzed data the level of significance was set at $p<0.05$ and a confidence interval of $95 \%$.

\section{Results}

One hundred forty-eight women from the city of XXX participated in the study, being 48 belonging to the group diagnosed with fibromyalgia and 100 women without fibromyalgia in the control group. No statistically significant differences were found in relation to the anthropometric characteristics, denoting paired groups regarding age, weight, height and body mass index $(p>$ 0.05) (Table 1).

Regarding the race $62.2 \%$ of women were white and $78.4 \%$ had some type of comorbidity. On the physical activity, only $20.3 \%$ of the participants practiced physical activity regularly, $48.6 \%$ of the participants had no depression. In the of sitting down and standing up test 45.7\% presented lower muscle strength. The genotypic frequency analysis for the SNP -1438 HTR 2A gene revealed that half $(50 \%)$ of the participants in the study were heterozygotes (AG), while $34.5 \%$ presented the genotype AA and only $15.5 \%$ had the genotype GG. The allelic frequency showed that the larger portion of the population studied (59.5) was the bearer of allele A (Table 2).

It was found a statistically significant association between ethnicity and patients with fibromyalgia, highlighted those of Caucasian ethnicity were 3.84 times more likely to develop the syndrome $(p=0.01)$. There was also an association between the variable comorbidity and fibromyalgia demonstrating that women with fibromyalgia have 9.85 times greater risk of developing some comorbidity $(p=0.01)$.

There was also an association between FM and the test to sit and stand up demonstrating that 36 women with fibromyalgia have lower limb muscle strength compared to the control group $(p=0.01)$.

The polymorphism -1438A/G (rs6311) of the HTR2A gene showed an association with fibromyalgia showing that carriers of the genotype GG and $G$ allele has a risk of 24.39 times more likely to develop thedisease (IC95\% 5.15-115.47; p = 0.01) (Table 3). But there was a correlation/association between the polymorphism of the gene, the muscular strength of limbs and fibromyalgia $(p>0.05)$.

Table 1 Characterization of the study population

\begin{tabular}{llll}
\hline Variable & $\begin{array}{l}\text { Control } \\
\text { Mean } \pm \text { SD }\end{array}$ & $\begin{array}{l}\text { Fibromyalgia } \\
\text { Mean } \pm \text { SD }\end{array}$ & Independent t test $(p)$ \\
\hline Age (years) & $52.05 \pm 12.19$ & $58.85 \pm 11.85$ & 0.55 \\
Weight $(\mathrm{kg})$ & $69.09 \pm 11.21$ & $74.05 \pm 15.44$ & 0.25 \\
Height $(\mathrm{m})$ & $1.61 \pm 0.09$ & $1.57 \pm 0.05$ & 0.23 \\
BMl $\left(\mathrm{Kg} / \mathrm{m}^{2}\right)$ & $26.52 \pm 3.22$ & $27.69 \pm 9.16$ & 0.47
\end{tabular}

Sd standard deviation, $\mathrm{Kg}$ kilogram, $\mathrm{m}$ meters, $B M \mathrm{l}$ body mass index 
Table 2 Distribution of socio-demographic characteristics, physical activity practice, functional test, genotypic and allelic frequency in women with and without fibromyalgia $(n=148)$

\begin{tabular}{|c|c|c|}
\hline Variables & $\mathrm{N}$ & $\%$ \\
\hline \multicolumn{3}{|l|}{ Bearer of Fibromyalgia } \\
\hline YES & 48 & 32.4 \\
\hline NO & 100 & 67.6 \\
\hline \multicolumn{3}{|l|}{ Age } \\
\hline Mean $(\mathrm{M} \pm \mathrm{DP})$ & \multicolumn{2}{|c|}{$62.57 \pm 10.65$} \\
\hline \multicolumn{3}{|l|}{ Race } \\
\hline White & 92 & 62.2 \\
\hline Non-White & 56 & 37.8 \\
\hline \multicolumn{3}{|l|}{ Comorbidities } \\
\hline YES (hypertension, heart disease and diabetes) & 116 & 78.4 \\
\hline NO & 32 & 21.6 \\
\hline \multicolumn{3}{|l|}{ Physical activity } \\
\hline YES & 30 & 20.3 \\
\hline NO & 118 & 79.7 \\
\hline \multicolumn{3}{|l|}{ Muscular strength of MSLL } \\
\hline Low Performance & 64 & 45.7 \\
\hline Normal Performance & 45 & 32.1 \\
\hline High performance & 31 & 22.1 \\
\hline \multicolumn{3}{|l|}{ Genotypic frequency HTR2A } \\
\hline GG & 23 & 15.5 \\
\hline AA & 51 & 34.5 \\
\hline$A G$ & 74 & 50 \\
\hline \multicolumn{3}{|l|}{ Allele frequency HTR2A } \\
\hline G & 120 & 40.5 \\
\hline$A$ & 176 & 59.5 \\
\hline
\end{tabular}

$M \pm S D$ Mean \pm Standard Deviation, MSLL lower limbs

\section{Discussion}

The present study investigated the association of the polymorphism of the gene $-1438 \mathrm{~A} / \mathrm{G} 5-\mathrm{HT} 2 \mathrm{~A}$ receptor in women with fibromyalgia. In this study, an association was found between fibromyalgia syndrome with the polymorphism of the serotonin receptor gene HTR2A in the promoter region $-1438 \mathrm{~A} / \mathrm{G}$, where $34.4 \%$ of the patients with fibromyalgia had the genotype GG, while only $6 \%$ of the control group presented this genotype, being that carriers of the genotype GG has 24.39 times more likely to develop the disease in comparison with those of genotype AA/GA.

Parsons et al. [29] showed that the SNP -1438A/G of the gene HTR2A is a functional SNP that affects the gene promoter activity by modulating its expression. The presence of the allele A significantly increases the gene activity in specific tissues where this gene is expressed. Thus, these findings suggest that this SNP $-1438 \mathrm{~A} / \mathrm{G}$ modulate the expression of the receptor gene 5-HTR2 in brain cells and should be responsible together with the SNP $102 \mathrm{~T} / \mathrm{C}$ for many neuropsychiatric phenotypes. The susceptibility to disease may be a reflection of the decrease of the receiver density, which is important for the neurotransmission mechanisms and is also connected to the cellular signaling, and studies show that reduced levels of serotonin have a correlation with the pain perception $[23,30,31]$.

These results differ from other studies that analyzed the same polymorphic region SNP -1438A/G [26, 27]. Tander et al. [26] evaluated 80 patients with fibromyalgia and 91 controls did not obtain statistically significant results among those with the SNPs of the gene 5-HTR2A $(-1438 \mathrm{~A} / \mathrm{G}$ and $102 \mathrm{~T} / \mathrm{C})$ and COMT and fibromyalgia $(p>0.05)$. Whereas in the survey conducted by Matsuda et al. [27] there was an association between fibromyalgia with the COMT gene, but the SNPs of the gene 5-HTR2A $(-1438 \mathrm{~A} / \mathrm{G}$ and $102 \mathrm{~T} / \mathrm{C})$ showed no such association.

It is worth mentioning that other studies have evaluated another SNP $(102 \mathrm{~T} / \mathrm{C})$ in gene 5-HTR2A. Lee et al. [20] conducted a systematic review in order to analyze the involvement of polymorphisms of the serotonin transporter gene (5-HTTLPR), catechol-O-methyltransferase (COMT) val158met and serotonin receptor 2A (5-HTR2A $102 \mathrm{~T} / \mathrm{C}$ ) and the susceptibility to fibromyalgia. In this study, it was not found an association between 5-HTTLPR genes and COMT with fibromyalgia. However, there was an association between the SNP $102 \mathrm{~T} / \mathrm{C}$ polymorphism of HTR2A gene with the syndrome, demonstrating that the $\mathrm{C}$ allele of SNP offers increased risk for the development of fibromyalgia, due to leading to a reduced expression of this gene.

Mergener et al. [21] analyzed the influence of the interaction between environmental quality and the SNP in the gene HTR2A $102 \mathrm{~T} / \mathrm{C}$ on the susceptibility of developing fibromyalgia in 41 patients with fibromyalgia and 49 control individuals, and showed that carriers of the $\mathrm{C}$ allele summed up to the variable low quality of health and social care, presented a risk 90 times greater of developing the syndrome $(p=0.005)$.

In addition, a correlation was also found between FM and the Caucasian ethnicity corroborating the findings of Walitt et al. [32]. Regal [33] conducted a study of epidemiological characteristics in patients with FM, and highlighted that women, aged 46 and 60 years old are most affected by the syndrome, and more than half has some psychological disorder associated and diagnosis of other comorbidities such as hypothyroidism.

The present study also found an association between fibromyalgia and the sitting down and standing up test demonstrating that women with fibromyalgia have lower limb muscle strength compared to the control group ( $p=$ 0.001). This result corroborates the findings of Cardoso et al. [4] in that evaluated the quality of life, strength and functional capacity of these patients, using the SF-36 questionnaire for quality of life, assessment of the strength of 
Table 3 Association among the variables race, comorbidities, muscle strength of lower limbs and allelic and genotypic frequencies

\begin{tabular}{|c|c|c|c|c|c|}
\hline \multirow{2}{*}{$\frac{\text { Variables }}{\text { Race }}$} & \multicolumn{2}{|c|}{ With FM } & \multicolumn{2}{|c|}{ Without FM } & \multirow{2}{*}{$\frac{\text { Value of } p}{0.001}$} \\
\hline & N & $\%$ & N & $\%$ & \\
\hline White & 39 & 81.3 & 53 & 53 & \\
\hline Non-White & 9 & 18.8 & 47 & 47 & \\
\hline \multicolumn{6}{|l|}{ Comorbidities } \\
\hline YES (hypertension, heart disease and diabetes) & 46 & 95.8 & 70 & 70 & 0.001 \\
\hline NO & 2 & 4.2 & 30 & 30 & \\
\hline \multicolumn{6}{|l|}{ Muscular strength of MSLL } \\
\hline Low Performance & 36 & 75.0 & 28 & 30.5 & 0.001 \\
\hline Normal Performance & 11 & 22.9 & 34 & 37.0 & \\
\hline High performance & 1 & 2.1 & 30 & 32.5 & \\
\hline \multicolumn{6}{|l|}{ Genotypic frequency } \\
\hline GG & 17 & 35.4 & 6 & 6 & 0.001 \\
\hline AA & 10 & 20.8 & 41 & 41 & \\
\hline$A G$ & 21 & 43.8 & 53 & 53 & \\
\hline \multicolumn{6}{|l|}{ Allele frequency } \\
\hline G & 55 & 64 & 65 & 32.5 & 0.001 \\
\hline$A$ & 31 & 36 & 135 & 67.5 & \\
\hline
\end{tabular}

FM: Fibromyalgia, MSLL lower limbs

one maximum repetition (1 RM) of knee flexion and extension, evaluations of forces of clamps and palmar prehension, and the 6-min walking test (TC6). Demonstrated that women with fibromyalgia have a reduction of functional capacity, increased pain and worsening of the general health status $(p<0.05)$.

Gois et al. [5] also evaluated the functional capacity, muscle strength and the risk of falls in women with fibromyalgia, by means of the following functional testing: 30-s sitting down and standing up test, time up and go, sitting and reaching and reaching functional test. Showed that carriers of the syndrome have deficits in lower limb muscle strength, balance and agility, showing a high prevalence of falls in this population, explained by the symptoms and pain caused by the disease.

Studies suggest that the reduction of muscle strength in patients with fibromyalgia has an important relationship with chronic pain and muscle fatigue [34]. It is worth mentioning that physical activity programs can help these patients for a better physical conditioning, and in addition to activating endogenous analgesic conditions, causing a sensation of well-being and consequently the improvement of the quality of life $[35,36]$.

In relation to the study limitations, the sample may have been insufficient to detect other interactions among the variables. It is possible to say that, for more assertive conclusions it is necessary to study a larger sample population and evaluate other polymorphisms of the gene combining an analysis of gene expression serotonin receptor HTR2A, for further clarification.
Concerning the clinical application of the results of the present study, the presence of association among fibromyalgia, the gene HTR2A, and the test muscular strength of lower limbs, shows that the from these assessments it is possible to identify a genetic characteristic and some limitations of patients with this disease, thus aiding in a better therapeutic approach.

\section{Conclusion}

It is concluded that white women with GG or G-allele genotypes are at greater risk of developing fibromyalgia and that these patients present lower limb muscle strength compared to the control group.

\section{Abbreviations}

5-HT: Serotonin; 5-HTTLPR: Serotonin transporter gene; ACR: American College of Rheumatology; COMT: Catecol-o-metiltransferase; DNA: Deoxyribonucleic acid; EDTA: Ethylenediamine tetra acetic acid; FM: Fibromyalgia; HTR2A: Serotonin Receptor 2A; MSLL: Muscular strength Lower members; PCR: Polymerase chain reaction; SNP: Polymorphism of a single nucleotide; SPSS: Statistical packege for social Science; TAG SNP: Polymorphism of a single nucleotide in linkage disequilibrium

\section{Authors' contributions}

Each author contributed individually and significantly to the development of the manuscript. LOL began to approach the research problem and participated in all stages: project construction, bibliographic research, data collection, data analysis, discussion of results, conclusion and writing of the manuscript. CAMZ, ASM and LRM-P participated in all stages, from project construction, data collection, data analysis, discussion of results, writing and critical review of the manuscript. DCT, KBPF and PDOP participated in data collection and analysis. RCPF participated in guiding all steps, from project construction, data collection, data analysis, discussion of results, manuscript writing and final review. All authors contributed strongly to the study. So all 
authors were responsible for all aspects of the work. All authors read and approved the final manuscript.

\section{Funding}

National Foundation for the Development of Private Higher Education (FUNADESP).

\section{Availability of data and materials}

The supporting data should be made available to the editors and reviewers for manuscript evaluation purposes. The authors offer and agree on the availability of data and materials from this study, as well as transfer the publication and reproduction rights to this journal.

\section{Ethics approval and consent to participate}

This study was approved by the Ethics Committee of the institution of University Pitágoras UNOPAR (3.057.780). All individuals have signed a written consent before any methodological procedure.

\section{Consent for publication}

Not Applicable

\section{Competing interests}

The authors declare that they have no competing interests.

\section{Author details}

${ }^{1}$ Rehabilitation Sciences State University of Londrina and University Pitágoras Unopar (UEL/UNOPAR), Londrina, PR, Brazil. ²Departament of Physical Education and Sport, Londrina State University (UEL), Londrina, Paraná, Brazil. ${ }^{3}$ Laboratory of Molecular Biology, Biological and Health Sciences Center, University Pitágoras Unopar, Rua Marselha, 591 Jardim Piza, CEP, Londrina, PR 86041-140, Brazil. ${ }^{4}$ University Anhanguera - UNIDERP (Universidade para o Desenvolvimento do Estado e da Região do Pantanal), Campo Grande, Mato Grosso do Sul, Brazil.

\section{Received: 18 June 2019 Accepted: 26 November 2019}

Published online: 26 December 2019

\section{References}

1. Lavín MM. Fibromialgia sem mistério: um guia para pacientes, familiares e médicos. São Paulo: MG Editores; 2014.

2. Talotta R, Bazzichi L, Di Franco M, Casale R, Batticciotto A, Gerardi MC, et al. One year in review 2017: fibromyalgia. Clin Exp Rheumatol. 2017;35(Suppl 105):6-12.

3. White KP, Speenchley M, Harth M, Ostrbye T. Comparing self-reported function and work disability in 100 comunity cases of fibromyalgia syndrome versus controls in London Ontario. Arthritis Rheum. 1999;42:76-83.

4. Cardoso FS, Curtolo M, Natour J, Lombardi JI. Avaliação da qualidade de vida, força muscular e capacidade funcional em mulheres com fibromialgia. Rev Bras Reumatol. 2011:51(4):338-50.

5. Góes SM, Leite N, Shay BL, Homann D, Stefanello JMF, Rodacki ALF. Functional capacity, muscle strength and falls in women with fibromyalgia. Clin Biomech. 2012;27(6):578-83.

6. Bernard AL, Prince A, Edsall P. Quality of life issues for fibromyalgia patients. Arthritis Care Res. 2000;13(1):42-50.

7. National Fibromyalgia Association (NFA). (2016). Prevalence. Disponível em: http://www.fmaware.org/about-fibromyalgia/prevalence. Acesso em: 03/12/2018.

8. Senna ER, De Barros AL, Silva EO, Costa IF, Pereira LV, Ciconelli RM, et al. Prevalence of rheumatic diseases in Brazil: a study using the COPCORD approach. J Rheumatol. 2004;31:594-7.

9. Cabo-Meseguer A, Cerdá-Olmedo G, Trillo-Mata JL. Fibromyalgia: Prevalence, epidemiologic profiles and economic costs. Med Clin (Barc). 2017;149:441-8.

10. Efrati S, Golan H, Bechor Y, Faran Y, Daphna-Tekoah S, Sekler G, Fishlev G, Ablin JN, Bergan J, Volkov O, Friedman M, Ben-Jacob E, Buskila D. Hyperbaric oxygen therapy can diminish fibromyalgia syndrome-prospective clinical trial. PLoS One. 2015;10(5):e0127012. https://doi.org/10. 1371/journal.pone.0127012. PMID: 26010952; PMCID: PMC4444341.

11. O'Brien AT, Deitos A, Triñanes Pego Y, Fregni F, Carrillo-de-la-Peña MT. Defective endogenous pain modulation in fibromyalgia: a meta-analysis of temporal summation and conditioned pain modulation paradigms. J Pain. 2018;19(8):819-36.

12. Bradley LA, McKendree-Smith NL. Central nervous system mechanisms of pain in fibromyalgia and other musculoskeletal disorders: behavioral and psychologic treatment approaches. Curr Opin Rheumatol. 2002;14:45-51.
13. D'Agnelli S, Arendt-Nielsen L, Gerra MC, Zatorri K, Boggiani L, Baciarello M, Bignami E. Fibromyalgia: Genetics and epigenetics insights may provide the basis for the development of diagnostic biomarkers. Mol Pain. 2019;15: 1744806918819944. https://doi.org/10.1177/1744806918819944. Epub 2018 Nov 29. PMID: 30486733; PMCID: PMC6322092.

14. Park DJ, Kang JH, Yin YR, Kim JE, Lee JW, Lee KE, et al. Exploring genetic susceptibility to Fibromialgia. Chonnam Med J. 2015;51(2):58-65.

15. Martins ACCL, Silva TM, Glorian BA. Determinação simultânea de precursores de serotonina - triptofano e 5-hidroxitriptofano - em café. Quim Nova. 2010;33(2):316-20.

16. Ren K. And R. Dubner. Pain facilitation and activitydependent plasticity in pain modulatory circuitry: role of BDNF-TrkB signaling and NMDA receptors. Mol Neurobiol. 2007:35(3):224-35.

17. Welsch P, Üçeyler N, Klose P, Walitt B, Häuser W. Serotonin and noradrenaline reuptake inhibitors (SNRIs) for fibromyalgia. Cochrane Database Syst Rev. 2018;2(2):CD010292.

18. Sparkes RS, Lan N, Klisak I, Mohandas T, Diep A, Kojis T, et al. Assignment of a serotonin 5 HT-2 receptor gene (HTR2) to human chromosome 13q14-q21 and mouse chromosome 14. Genomics. 1991;9:461-5.

19. Kling A, Seddighzadeh M, Arlestig L, Alfredsson L, Rantapaa-Dahlqvist S, Padyukov L. Genetic variations in the serotonin 5-HT2A receptor gene (HTR2A) are associated with rheumatoid arthritis. Ann Rheum Dis. 2008;67:1111-5.

20. Lee $Y H$, Choi SJ, Ji JD, Song GG. Candidate gene studies of fibromyalgia: a systematic review and metaanalysis. Rheumatol Int. 2012;32:417-26.

21. Mergener M, Becker RMR, Santos AF, Santos GA, Andrade FM. Influência da interação entre qualidade ambiental e o SNP T102C do gene HTR2A sobre a suscetibilidade à fibromialgia. Rev Bras Reumatol. 2011;51(6): 594-602.

22. Myers RL, Airey DC, Manier DH, Shelton RC, El S-B. Polymorphisms in the regulatory region of the human serotonin 5-HT2A receptor gene (HTR2A) influence gene expression. Biol Psychiatry. 2007;61(2):167-73.

23. Buskila D. Developments in the scientific and clinical understanding of fibromyalgia. Arthritis Res Ther. 2009;11:242.

24. Correa H, Marco LD, Boson W, Nicolato R, Teixeira AL, Campo VR, RomanoSilva MA. Association study of T102C 5-HT2A polymorphism in schizophrenic patients: diagnosis, psychopathology, and suicidal behavior Dialogues Clin Neurosci. 2007;9:97-101.

25. Sahin G, Ulubas B, Callkoglu M, Erdogan C. Handgrip strength, pulmonary function tests, and pulmonary muscle strength in fi bromyalgia syndrome: is there any relationship? South Med J. 2004;97(1):25-9.

26. Tander B, Gunes S, Boke O, Alayli G, Kara N, Bagci H, et al. Polymorphisms of the serotonin-2A receptor and catechol-Omethyltransferase genes: a study on fibromyalgia susceptibility. Rheumatol Int. 2008;28:685-91.

27. Matsuda JB, Barbosa FR, Morel LJF, França SC, Zingaretti SM, Silva LM, et al. Polimorfismos dos genes do receptor de serotonina (5-HT2A) e da catecolO-metiltransferase (COMT): fatores desencadeantes da fibromialgia? Rev Bras Reumatol. 2010;50(2):141-5.

28. Wolfe F, Clauw DJ, Fitzcharles MA, Goldenberg DL, Häuser W, Katz RS, et al. Fibromyalgia criteria and severity scales for clinical and epidemiological studies: a modification of the ACR preliminary diagnostic criteria for fibromyalgia. J Rheumatol. 2011:38:1113-22.

29. Parsons MJ, D'Souza UM, Arranz MJ, Kerwin RW, Makoff AJ. The -1438A/G polymorphism in the 5-hydroxytryptamine type 2A receptor gene affects promoter activity. Biol Psychiatry. 2004;56:406-10.

30. Guillet-Deniau I, Burnol AF, Girard J. Identification and localization of a skeletal muscle secrotonin 5-HT2A receptor coupled to the Jak/STAT pathway. J Biol Chem. 1997;272:14825-9.

31. Offenbaecher M, Bondy B, de Jonge S, Glatzeder K, Krüger M, Schoeps P, et al. Possible association of fibromyalgia with a polymorphism in serotonin transporter gene regulatory region. Arthritis Rheum. 1999;42(11):2482-8.

32. Walitt B, Nahin RL, Katz RS, Bergman MJ, Wolfe F. The prevalence and characteristics of fibromyalgia in the 2012 National Health Interview Survey. PLoS One. 2015;10(9):1-16.

33. Regal Ramos RJ. Características epidemiológicas de los pacientes evaluados por fibromialgia en la Unidad Médica de Valoración de Incapacidades de Madrid. Semergen. 2017:43(1):28-33.

34. Nordenskiold UM, Grimby G. Grip force in patients with rheumatoid arthritis and fibromyalgia and in healthy subjects: a study with the Grippit instrument. Scand J Rheumatol. 1993;22(14):14-9.

35. Williams DA, Clauw DJ. Understanding fibromyalgia: lessons from the broader pain research community. J Pain. 2009;10(8):777-91. 
36. Jones CI, Rikli RE, Beam WC. A 30-s chair-stand test as a measure of lower body strength in community-residing older adults. Res Q Exerc Sport. 1999;70(2):113-9.

\section{Publisher's Note}

Springer Nature remains neutral with regard to jurisdictional claims in published maps and institutional affiliations.

Ready to submit your research? Choose BMC and benefit from:

- fast, convenient online submission

- thorough peer review by experienced researchers in your field

- rapid publication on acceptance

- support for research data, including large and complex data types

- gold Open Access which fosters wider collaboration and increased citations

- maximum visibility for your research: over $100 \mathrm{M}$ website views per year

At $\mathrm{BMC}$, research is always in progress.

Learn more biomedcentral.com/submissions 